\title{
Optimisation of hybrid renewable energy systems on islands: A review
}

\author{
James Morales Lassalle \\ Faculty of Engineering, Universidad de Concepción, Concepción \\ jmoralesl@udec.cl (corresponding author)
}

\section{Dante Figueroa Martínez \\ Department of Geophysics, Universidad de Concepción, Concepción \\ dantefigueroa@udec.cl}

\section{Luis Vergara Fernández}

Faculty of Engineering, Universidad de Concepción, Concepción

Ivergaraf@udec.cl

\begin{abstract}
Access to energy services is recognised as a fundamental aspect of economic and social development. This is particularly important for isolated areas, where electrical supply is not guaranteed. Because of their inherent geographic characteristics, islands are prominent cases of isolated areas that must import and burn fossil fuels, with environmental and economic consequences. In this context, Hybrid Renewable Energy Systems (HRES) emerge as an alternative to traditional generation to reduce energy costs and environmental issues. This study aims to demonstrate the feasibility of implementing HRES on islands, based on energy optimisation. We present an extensive review of HRES optimisations across 73 island cases, collecting information about energy demand, energy system sizes, and optimisation methodologies. The most commonly proposed HRES components are identified, and a significant power relationship is found between population and annual energy demand on islands. Further, we identify islands with higher-than-expected and lower-than-expected consumption and the underlying causes. The main limitations of the reviewed studies are discussed, particularly with regards to availability and quality of hourly demand data and/or meteorological data required for renewable energy assessments. Several approaches to fill these gaps in information are reviewed here, concluding with a discussion of emergent methods and technologies.
\end{abstract}

Keywords: energy optimisation, hybrid renewable energy systems, islands, renewable energy, review

https://doi.org/10.24043/isj.167 • Received October 2020, Early access June 2021

(C) Island Studies Journal, 2022 


\section{Introduction}

Access to and quality of electrical supply is a fundamental goal for all nations in order to guarantee sustainable development. This is internationally recognised in policies and recommendations like the seventh of the United Nations Sustainable Development Goals (SDGs), "Ensure access to affordable, reliable, sustainable and modern energy for all", approved by 193 world leaders in 2015 (United Nations, 2015). In this context, it is necessary not only to guarantee access to energy, but also to implement sustainable ways to obtain it, which involves an increase in the share of renewable energies, improvement in energy efficiency, and international cooperation in related research and technology.

Even though global access to electricity increased from 73\% to $89 \%$ between 2000 and 2018, some regions, such as sub-Saharan Africa (45\% access to electricity) and some regions in Asia, persist in having a lack of access to energy. Globally, close to 0.9 billion people have no access to electricity - mainly in rural or isolated areas (International Energy Agency, 2019). At the same time, energy access is a critical issue for economic and social development of isolated areas. Y. Liu et al. (2018, p. 460) define an "isolated area" as a region that meets some of the following characteristics: large distances to population centres, limited access to utility grids, high dependence on imported energy, and inconvenient transportation. In this context, islands are prominent examples of isolated areas.

According to Kuang et al. (2016), more than 740 million people live on islands, and most of their power systems depend heavily on imported fuels for generation - with economic and environmental consequences (Ioannidis \& Chalvatzis, 2017; Krajačić et al., 2008). In the same sense, it is recognised that economic and social development on islands is closely related to availability of energy sources, supply of fresh water, management of waste, and transportation (Aguirre-Mendoza et al., 2019), all of which are energy-related.

An alternative that has attracted attention in recent decades is hybrid renewable energy systems (HRES), which allow greater flexibility, higher reliability and efficiency, and lower energy costs compared with traditional pure diesel generation (Mohammed et al., 2016). Additionally, HRES reduce transportation risks and system instabilities, encouraging the sustainability of the island energy system.

This study aims to evaluate the feasibility of HRES implementation on islands around the world, analysing a wide range of cases in terms of both energy demand and population. Likewise, it is important to identify which aspects of HRES optimisation are most critical, taking into account environmental and geographical conditions of islands. For this purpose, an exhaustive review of hybrid energy systems on islands was carried out, examining 73 island cases and delving into optimisation processes, optimisation methodologies, objectives, most commonly proposed HRES components, and main barriers to researchers.

\section{Hybrid renewable energy systems}

Due to their availability and technological maturity, diesel engine generators have been the most common method of providing electricity to isolated communities in recent decades (Kennedy et al., 2017). However, significant impacts on the environment related to the use of fossil fuels are a cause for concern (Mahesh \& Sandhu, 2015). At a local level, there are potential environmental risks related to the transport of diesel by ships, polluting emissions, 
and often high costs of the energy (Kuang et al., 2016). These features are particularly significant on islands around the world, given their dependence on imported fossil fuels as an exclusive energy source (Gils \& Simon, 2017; Segurado et al., 2011). At the same time, on a global scale, the extensive use of fossil fuels for electricity generation has transformed the energy sector into the main contributor of greenhouse gases (International Energy Agency, 2018). Furthermore, islands are very sensitive and vulnerable to the potential negative impacts of worldwide issues, such as global warming (Blechinger et al., 2016; Mendoza-Vizcaino et al., 2016).

To diminish the risks related to conventional electricity generation (diesel), reduce the cost of energy, and provide greater reliability to the energy system, some islands are gridconnected to the mainland - but, in most cases, this is not economically feasible due the cost of undersea cables (Aguirre-Mendoza et al., 2019; H. Liu \& Qu, 2014). Many studies therefore recommend local harnessing of renewable energies to decrease the emission of pollutants and greenhouse gases and make advances in energy independence and energy cost reductions (Blechinger et al., 2016; Kaldellis et al., 2012; Orhan et al., 2014).

Several authors have recognised renewable energy systems (RES) as a logical alternative for islands because they usually have significant renewable energy potentials (Dorotić et al., 2019; Enevoldsen \& Sovacool, 2016; Katsaprakakis, 2016; H. Liu \& Qu, 2014; Meza et al., 2019; Segurado et al., 2011). Nevertheless, RES are not always capable of fulfilling the energy demand, and it becomes necessary to complement them with conventional backup units (Siddaiah \& Saini, 2016) or with storage units that help to minimise the unmet load by absorbing any energy surplus of the renewable units (El-Bidairi et al., 2018; Katsaprakakis, 2016; Papaefthymiou et al., 2015). Generation systems that have more than one source, including at least one renewable source, are called hybrid systems. Manwell (2004, p. 215) defined hybrid energy systems as the combination "of two or more energy conversion devices [...] that when integrated, overcome limitations that may be inherent in either." To use two or more suitable energy sources (with at least one being a renewable source) could improve the efficiency and reliability, thus overcoming economic limitations arising from a single energy source (Siddaiah \& Saini, 2016; Thomas et al., 2016). The technical and environmental performances of HRES, as well as lower costs, have been demonstrated in many studies (Drouineau et al., 2015; Lin et al., 2016; Ma et al., 2014; Thomas et al., 2016).

\section{Review of HRES on islands}

For this study, any paper addressing HRES optimisation on islands published by an indexed journal was initially considered. However, some studies were then excluded due to their lack of detailed information regarding the optimisation process they used. Only cases with sufficient information were included in the final list. A complete list of the 73 islands is presented in Appendix A.

\subsection{HRES optimisation}

In an overview of the reviewed case studies, three well-defined stages of HRES optimisation can be described (see Figure 1): 
- Renewable energy potential assessment: Depending on the specific features of the island, wind, solar, hydroelectric, and other renewable resources should be assessed to evaluate the overall energy potential. Several decisions must be made at this stage, such as which form of energy should be prioritised for harnessing. This decision can consider economic and/or technological criteria, e.g., technology maturity, reliability, and costs (Brito et al., 2014).

- Energy consumption assessment: Energy demands of islands can be very different compared with the demands on the mainland. Therefore, simply assuming a direct correlation with population is not necessarily a good strategy for assessing island demand (Brito et al., 2014). This applies not only for the magnitude of the demand but also for its daily variability (produced by different economic activities, e.g., tourism, fishery, services, manufacturing, farming); social issues (e.g., low household incomes); and external subsidies. This information is often not available for islands, and researchers must therefore use different approaches and estimations.

- Sizing and energy optimisation: At this stage, the number and capacity of the HRES elements are evaluated to minimise/maximise the objective functions (i.e., unmet energy, net present cost, cost of energy, etc.) and ensure all constraints are satisfied (Bahramara et al., 2016).

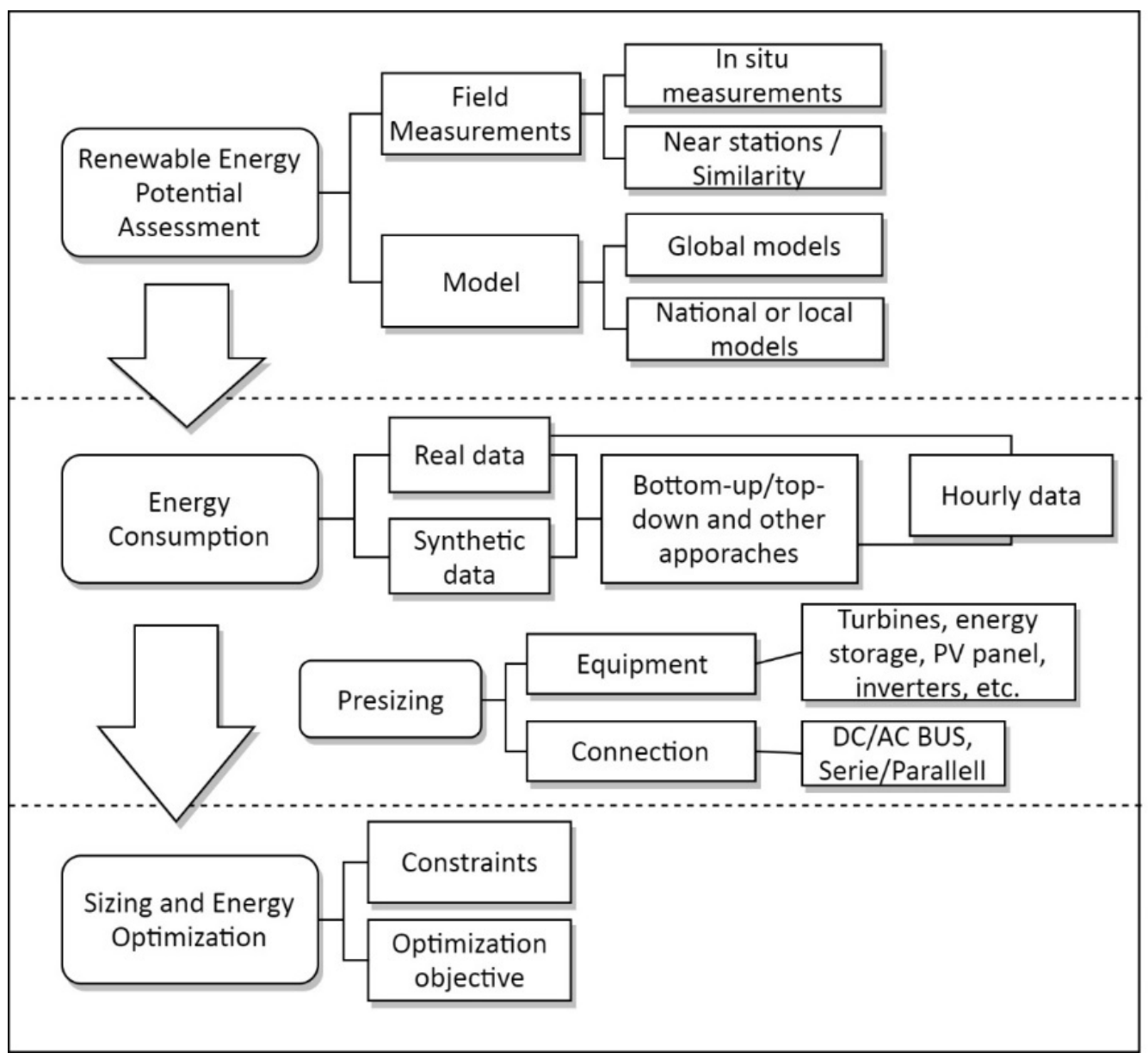

Figure 1. Three stages in HRES optimisation: renewable energy assessment, energy consumption assessment, and sizing and energy optimisation. Source: Authors' own elaboration based on the reviewed cases. 


\subsection{Geographic and demographic aspects}

Most of the studied islands lie in the northern hemisphere, mainly in Europe and Asia. Specifically, 30 cases are in Europe, 29 in Asia, 9 in the Americas, 3 in Oceania, 1 in Africa, and 1 in Europe/Asia. The country with the most analysed cases is, by far, Greece, with 13 islands in ten different research works, followed by Croatia with four islands from four papers.

The population of each analysed island varies from 20 people (Mykines, Faroe Islands) to 8.6 million (Hainan Island, China), allowing examination of a wide range of cases. A detailed list of the populations of the studied islands is presented in Appendix A.

As mentioned earlier, the economic activity of an island is crucial for both its level of energy demand and its load pattern. In many of the islands studied (32 cases), tourism is the main economic sector. In six cases, tourism was identified as one of the main economic activities, together with agriculture, fishing, and livestock and dairy products. This aspect is very relevant considering its effect on seasonal demand (Kougias et al., 2019), which leads to more intensive energy consumption during some months of the year due the swelling population of the island. In the span of one year, tourists can easily outnumber the permanent population of an island. The population of St Martin's Island (Bangladesh), for example, is about 8000 inhabitants, but it is visited by more than 30,000 people throughout the year (Mazumder et al., 2014).

\subsection{Energy demand}

The system size (annual energy demand) of the analysed cases varies significantly, from Mykines with the lowest consumption $(0.157 \mathrm{MWh} /$ year) to Hainan with the highest $(12,000 \mathrm{GWh}$ /year, comparable to whole countries such as Ecuador or Bolivia). It is possible to define four sizes (quartiles) associated with the annual energy demand (see Table 1).

Table 1. Energy system size classification.

\begin{tabular}{ll}
\hline System classification & Size $(\mathbf{M W h} /$ year) \\
\hline Small size & $0-650$ \\
Medium size & $651-9950$ \\
Large size & $9951-98,600$ \\
Very large size & $>98,600$ \\
\hline
\end{tabular}

All of the studied cases are presented in Figure 2, where a power relationship between the variables is revealed. It is worth noting the good agreement between the real annual energy demand data and the values predicted by the fitting, with a (logarithmic) slope of approximately 1.16 and an $\mathrm{R}^{2}$ value of 0.85 . This relation is significant, and each of the two variables in logarithmic form follows a normal distribution. The relation holds even when highly developed island countries with large populations (i.e., UK, Taiwan, Japan) are added, even though they were not included in the curve fitting.

It is interesting to analyse how far every island's energy is from the predicted curve. Islands with values below the curve are associated with lower-than-expected consumption, which in turn is related mainly to primary economic activities or even a subsistence economy. The Mykines island economy, for example, is related mainly to low-impact tourism and sheep farming. Similarly, the economy of Isla Tac (Chile) is based on fishing, and further similarities are observed for Isla Santay (Ecuador), Lençóis (Brazil), Ometepe (Nicaragua), São Vicente 
(Portugal), and Malé (Maldives). Even on Hainan Island, with a substantially larger population, the economic activity mainly involved agriculture, with incipient industrial activity at the time of the study (Ye et al., 2012). In contrast, values over the curve are related to secondary and tertiary economic activities, particularly manufacturing and tourism, for example in Awaji (Japan), Karpathos-Kasos (Greece), or Yong Shu Island, in the South China Sea.

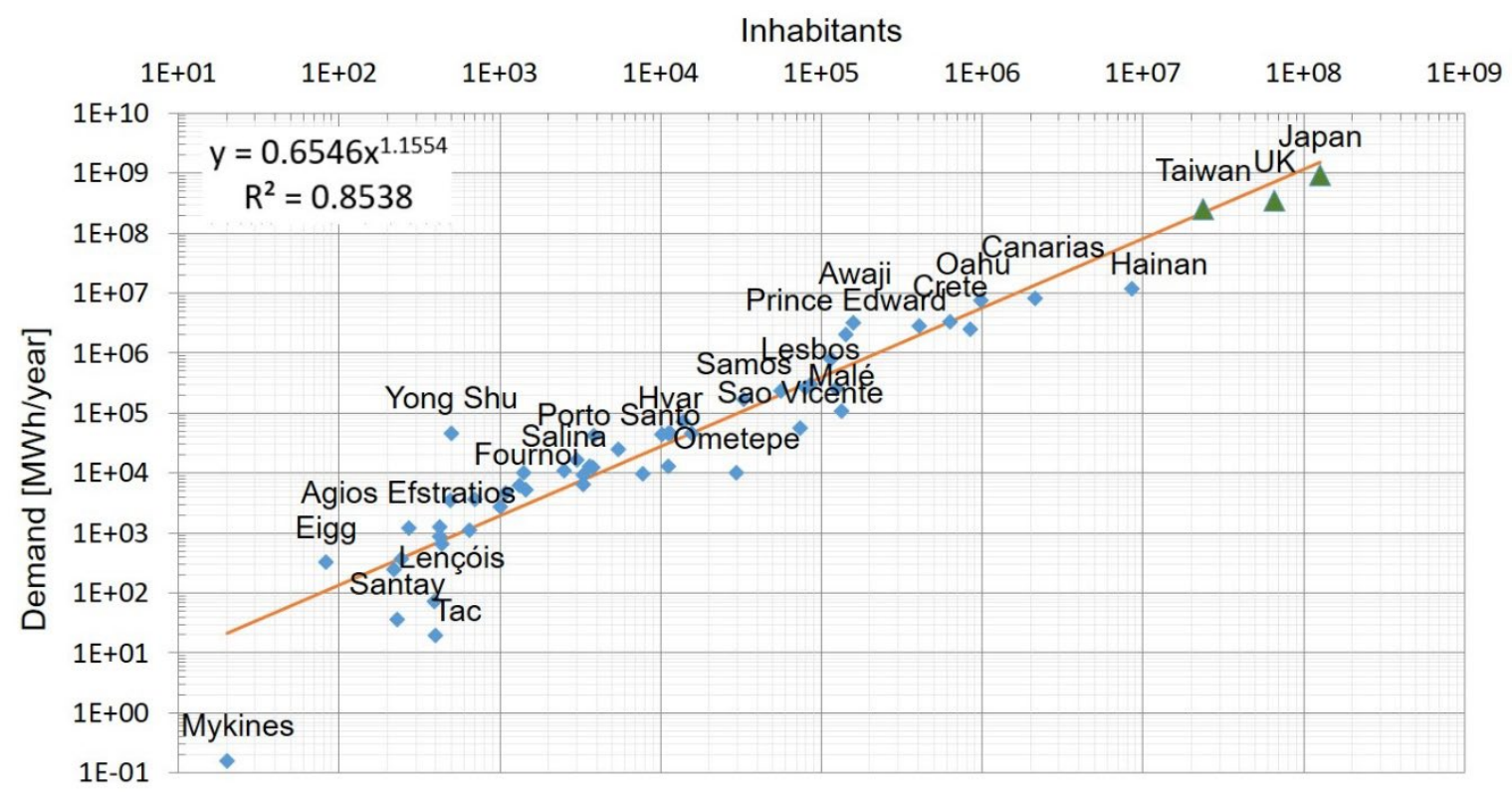

Figure 2. Demand and population of the analysed islands (blue dots); axes are logarithmically scaled. An exponential adjustment between both variables is also shown. Note: UK, Taiwan, and Japan (green triangles) added for comparison and are not included in curve fitting.

\subsection{Energy load profiles}

Perhaps the most fundamental information for performing an energy optimisation is the demand data. Although this information, at least in terms of annual or monthly averages, is usually accessible for big cities, it may not be available for islands. Very frequently, researchers rely on just general information about the demand and must resort to models or other approaches to obtain hourly data.

In the case of our study, just 17 of the 73 analysed islands had measured data; in some cases, only monthly (or even annual) average consumption data were available. Different approaches can be used to address this problem, such as estimations based on average consumption for typical homes, use of software containing a database of consumption patterns, or just scaling the required demand data from a known consumption in a similar location. In general, these techniques can be grouped in top-down or bottom-up approaches. These will now be discussed.

\section{Top-down methods}

Senjyu et al. (2007) propose an optimal hybrid configuration for Miyako, Kume, and Tokashiki islands, in the prefecture of Okinawa, Japan. To obtain power demand information, they multiplied the peak power demand with the power demand ratio for mainland Okinawa. For this case, the power demand ratio for the mainland was 1/25, 1/100, 
and 1/324 for Miyako, Kume, and Tokashiki, respectively. Similarly, Sakaguchi and Tabata (2015) estimated the energy demand for Awaji Island by using energy consumption statistics from the Hyogo Prefecture.

On the other hand, Park and Kwon (2016) used synthesised hourly demand data generated with Hybrid Optimization of Multiple Energy Resources (HOMER) software, which is based on scaled annual demand and peak energy data. This information was collected from the Korea Electric Power Corporation for Gadeokdo Island (South Korea). A similar method was used by Demiroren and Yilmaz (2010) for Gökceada, Turkey.

Finally, Shin et al. (2015) used a combination of top-down and bottom-up techniques to obtain the hourly data for Deokjeok Island in South Korea. The authors did not rely on demand data, apart from the annual demands of 2012 and 2013. However, they had monthly consumption for Ongjin District, separated by categories. They assumed the same electric patterns for both locations and scaled down to the annual data of Deokjeok (Shin et al., 2015). To derive hourly data, they used EnergyPlus software, which enables acquisition of hourly consumption data based on building models under specific weather conditions and facility operation schedules.

In general, it should be taken into account that top-down approaches usually assume a typical load profile of continental cities, which will not necessarily represent a load profile of an island. They do, however, allow a better approximation of annual demands than bottomup approximations, discussed next.

\section{Bottom-up methods}

A bottom-up approach was used in several forms in the examined cases. In Isla Grande (Colombia; Aguirre-Mendoza et al., 2019), the energy demand was estimated considering a set of electrical appliances and the average consumption for a typical native house in the Caribbean region. A similar method was applied in Saint Martin's (Mazumder et al., 2014), where the authors classified families into three groups depending on their income: very solvent, solvent, and poor. For each case, specific appliances were assumed with a determined consumption pattern. Other assumptions included daily random variability and time-step variability (Mazumder et al., 2014).

Ye et al. (2017) presented a case study for Yong Shu Island, a strategic port in the South China Sea. To evaluate the future demand, the authors relied on the standards of building electricity demand in China and the planned construction floor area. For instance, 200,000 $\mathrm{m}^{2}$ of the port area was considered and, as the standard consumption for this kind of area is $150 \mathrm{kWh} / \mathrm{m}^{2} /$ year, the total electricity demand was calculated as 30,000 MWh per year. Chua et al. (2014) proposed a sustainable energy system for Pulau Ubin, Singapore. To achieve this, they assumed hypothetical facilities, including hotels, resorts, restaurants, and residential homes, and simulated hourly energy use for these specific buildings.

Bottom-up approximations tend to be more precise than top-down methods in representing daily consumption variability, to the extent that consumption loads are well characterised (e.g., residential, commercial, industrial). However, by assuming the same load profile within a category, the possible inefficiencies of any particular load are overlooked, affecting the characterisation of the represented category. 


\subsection{Renewable energy resource assessment}

Islands usually have considerable renewable energy potential (Dorotić et al., 2019; Enevoldsen \& Sovacool, 2016; Katsaprakakis, 2016; Meza et al., 2019). However, for correctly sizing an HRES, a good assessment of the available resources is fundamental. Aspects that are inherent to renewable energies, such as intermittence, strong seasonality, and low-energy periods, can adversely affect electricity generation. Unfortunately, as is the case for demand data, renewable energy resource data are often incomplete or not available. This is especially important for islands with no previous energy system implemented. Researchers have employed several approximations when real data are not available, such as by using global models (Aguirre-Mendoza et al., 2019; Ahadi et al., 2016; Basir Khan et al., 2015; Enevoldsen \& Sovacool, 2016; Lata-García et al., 2017; Mazumder et al., 2014; Orhan et al., 2014; Park \& Kwon, 2016; Ye et al., 2017), historical data (Aguirre-Mendoza et al., 2019; Andaloro et al., 2012; van Alphen et al., 2007), or comparison with a place with similar weather conditions (Basir Khan et al., 2015; Senjyu et al., 2007).

It should be noted that most of the hybrid systems studied in this paper consider just wind and/or solar energy, likely given their technological maturity and the wide availability of these resources. As mentioned previously, however, meteorological data are not always available. For instance, when real solar radiation data are not available, researchers typically use global models like NASA Prediction of Worldwide Energy Resource (POWER; https://power.larc.nasa.gov) or algorithms such as the Graham-Hollands algorithm (Graham \& Hollands, 1990), a stochastic method for generating synthetic hourly irradiation values. This algorithm is used, for example, in the energy optimisation software HOMER. In contrast, wind data are, in general, measured on-site. When local wind data are not available, authors usually use data from other periods, assuming that the medium- and long-term variability does not significantly affect the estimation of the wind potential. In a few cases, data from nearby places are used. For example, in the study carried out by Basir Khan et al. (2015) for Tioman Island (Malaysia), the meteorological station they used was not on Tioman but in Mersing, a coastal town $32 \mathrm{~km}$ away from the island.

Global models allow a quick but not necessarily accurate estimation of the renewable energy resources; these can be a good initial step if measured data are not available. The performance of global models for solar radiation, however, is usually quite acceptable, which is evidenced by the extensive use of tools such as HOMER or NASA POWER.

Table 2 summarises the sources of wind and solar data of the analysed studies, divided into three categories: instrumental, modelled, and synthesised using software or an algorithm. It can be observed that, in most cases, the winds are actually measured, whereas the solar irradiation data can come from any source.

Table 2. Sources of wind and solar data used in the analysed studies.

\begin{tabular}{llll}
\hline & Instrumental & Model & Software/Algorithm \\
\hline Wind & 41 & 11 & 2 \\
Solar & 16 & 16 & 15 \\
\hline
\end{tabular}




\subsection{Optimisation objectives}

The optimisation objective, or the objective function that the methodology will either maximise or minimise, can imply significant differences in the sizing of the final system. Depending on the objective, aspects such as restrictions on the RES penetration, generation technology, energy sources, or energy storage systems could be favoured at the expense of, for example, higher cost of energy (COE). In contrast, if the objective function is one that minimises such aspects as net present cost (NPC), internal rate of return (IRR), or another economical objective, the energy mix could not reach the maximum RES penetration or some environmental indicators (greenhouse gases, pollutant emissions, etc.). From the analysed studies, the four suitable categories of optimisation objectives are the economic, environmental, technical, and multi-objective approach. Each of these will now be discussed.

\section{Economic objectives}

One of the main criteria that an isolated system must meet is that the total investment becomes economically viable, i.e., the cost of the energy is able to keep the system working. In this context, $44.4 \%$ (32) of the studied cases present an optimisation regarding economic objectives, such as NPC, COE, IRR, payback period, cost of operation, life cycle cost, and/or others of a similar nature. This is the most common optimisation criterion for islands.

\section{Environmental objectives}

Environmental optimisation objectives involve aspects such as minimising $\mathrm{CO}_{2}$ emissions, maximising RES penetration, and/or evaluating the possibility of $100 \%$ RES. In fact, most of the studies in this category evaluate different levels of RES penetration, with the goal of reaching $100 \%$. Indeed, this is an ambitious objective, usually related to national or global goals. Of the analysed islands, $26 \%$ considered environmental criteria for optimisation. In the case of Mykines (Enevoldsen \& Sovacool, 2016), for instance, the authors conclude that it is technically possible to combine wind turbines, electrolysers, and fuel cells to reach $100 \%$ RES. They recognise that, in this case, diesel-based systems produce energy at a cheaper levelized cost, but that it is necessary to "slightly compromise reliability and maturity of technology" (Enevoldsen \& Sovacool, 2016, p. 647) to achieve a self-sufficient system and a 100\% RES, considering its "immense benefits to the environment" (Enevoldsen \& Sovacool, 2016, p. 647).

It can be observed that, generally, any alternative that involves a high RES penetration will imply, in turn, yielding in another aspect (e.g., economical). In this sense, some studies justify a $100 \%$ RES based on positive externalities, for example for encouraging tourism or the willingness of consumers to pay for tourism services. This argument is present in H.-Y. Liu and Wu's (2010) case study of Kinmen (Taiwan), where it is recognised that the island will experience a significant increase in population in coming years, with a consequent increase in electricity consumption, in addition to large-scale environmental pollution. They conclude that a 100\% RES would provide new jobs, tourism, and investment opportunities (H.-Y. Liu \& Wu, 2010).

It is noted that environmental optimisation objectives are focused mainly to reducing $\mathrm{CO}_{2}$ emissions and maximising RES penetration level. Other approaches, such as life cycle analysis over the HRES components or social implications of the renewable energy infrastructure, are generally not addressed. 


\section{Technical objectives}

Technical optimisation objectives aim to evaluate the performance of HRES in different operation conditions, not necessarily restricted to economical or environmental criteria. Only two cases with these characteristics were identified. Corsini et al. (2009) assessed the performance of two renewable energy buffering strategies to balance seasonally varying electricity demand (through a hydrogen-based system) or to satisfy the water requirement (through a desalinated water production system) for Ventotene Island (Italy) by converting the available renewable energy surplus. In Fournoi (Greece; Bertsiou et al., 2018), the authors propose taking advantage of the natural topography of the island by using a pumped storage system (PSS) and, consequently, hydroelectric power. The objective is to evaluate the feasibility of covering part of the electrical requirements and, through a desalination plant, satisfying the water requirements of the island.

\section{Multi-objective approaches}

If two or more optimisation objectives are simultaneously taken into account, the problem may arise that they could be inherently opposed to each other. For example, minimising $\mathrm{CO}_{2}$ emissions possibly involves higher NPC, and minimising levelized cost of energy (LCOE) is contrary to maximising RES penetration. Multiobjective optimisation was applied in $12 \%$ (9) of the studied cases.

Mourmouris and Potolias (2013) present an evaluation framework to support energy planning based on RES for Thassos, Greece. The optimal energy mix is evaluated with a multi-criteria decision analysis tool. There are four evaluation criteria in their study: economical, environmental, social, and technical/technological (Mourmouris \& Potolias, 2013). Papaefthymiou and Papathanassiou (2014) investigate the optimum sizing for a PSS for HRES on Lesbos Island. Their analysis considers two perspectives: that of an investor and that of the system. In the first case, the objective is to maximise the return on investment through a single-objective optimisation algorithm (Genetic Algorithm; Papaefthymiou \& Papathanassiou, 2014). In the second case, the objective is to maximise RES penetration through a multi-objective evolutionary algorithm (MOEA). Here, the problem is to determine the optimum size of the system that maximizes RES penetration while simultaneously minimising the increase in the overall generation cost.

\subsection{Optimisation methodologies}

Numerous energy optimisation tools and frameworks have been developed and widely discussed in reviews (Y. Liu et al., 2018; Sinha \& Chandel, 2014). Their use in HRES optimisation allows researchers to describe, model, and analyse the operation and performance of the system, which is particularly important given the unique characteristics of islands. HOMER software is, by far, the most used optimisation and sizing energy tool of the studied cases. This application, thoroughly reviewed in Bahramara et al. (2016), was designed for small, isolated energy systems, making it particularly suitable for HRES on islands. HOMER was applied in 22 cases, eight of which were in combination with another optimisation tool. Techno-economical models were applied in 10 cases. 


\subsection{Energy mix}

\section{Generation}

Of the total number of studied cases, $93.2 \%$ (68 cases) consider wind energy as one, but not the only, alternative, followed by $83.6 \%$ (61 cases) considering solar energy (either photovoltaic energy or concentrated solar power).

Diesel generation still has an important role in the HRES, having been considered in $54.8 \%$ (40) of the cases. This last result confirms that diesel generation is a reliable alternative as backup.

It should be mentioned that in 13 cases, the harnessing of hydroelectric energy was proposed, as it is usually available on islands in the form of pumped storage, making use of the renewable energy surplus that would otherwise be lost.

In a few cases, just one kind of renewable energy was considered. For example, in Utsira Island (Norway; Ulleberg et al., 2010), the system only considered wind energy in a small demonstration plant (ten households), with a hydrogen storage system. The aim of this study was to evaluate the performance of the system using updated tools for modelling a hydrogen energy system, to eventually achieve a 100\% autonomous power system. On Mykines (Enevoldsen \& Sovacool, 2016, p. 642), the researchers justified their decision based on the "strong wind energy potential," as the Modern-Era Retrospective analysis for Research and Applications (MERRA) mesoscale model indicated an average wind speed of $9.31 \mathrm{~m} / \mathrm{s}$ at $10 \mathrm{~m}$ height. The extremely small population of the island - just 20 inhabitants at the time of the study - could justify that only one renewable source is needed to supply the complete demand.

As the HRES mix is of course related to the available resources on each island, some sources will take priority over others. Despite the geographic and meteorological differences between islands, the current study found that certain energy mixes are typically proposed. The most typical generation mix was the harnessing of wind and solar energy with diesel generation as backup; this combination was preferred in 29 cases.

\section{Energy storage}

To increase the RES penetration on islands, use the surplus renewable generation, or, in general, improve the performance of the entire system, most studies consider at least one type of storage system. It was found that in 62 cases the authors proposed a storage system and, of the remaining 11 cases, four (Awaji, Hainan, Cozumel, and Mykonos) are grid connected. Electrochemical batteries are considered on 44 cases, pumped storage on 12 cases, and hydrogen storage on 11 cases. In two cases (Yong Shu and Utsira), the possibility of using flywheels was evaluated.

In most cases, the energy storage systems are denoted simply as "batteries", and the researchers do not specify what kinds of electrochemical batteries were considered. When specified, batteries are reported to be lead-acid, lithium-ion, sodium sulphur, nickel cadmium, and redox flow batteries.

PSS are recognized by several authors as the most mature storage technology for medium and large systems (Bertsiou et al., 2018; Katsaprakakis, 2016; Papaefthymiou \& Papathanassiou, 2014). Use of PPS in isolated systems, such as on islands, is generally in combination with a wind generation system to recover the surplus energy. Of the studied cases, 12 suggest using a PSS. Further, the proposal for a specific energy storage system was found to be related to the size of the system (see Table 1). The studied cases present a 
preponderance of electrochemical battery storage in small systems, which decreases as the size of the system increases. The opposite happens with PSS storage, which tends to grow in importance as the system size increases. Hydrogen storage systems appear to show no correlation with the size of the system.

Finally, considering generation and storage, the most common hybrid energy mix is wind/solar/diesel with electrochemical battery $(34.2 \% \quad[25$ cases $])$, followed by wind/solar/electrochemical battery in $8.2 \%$ (6) cases. The main HRES mixes are presented in Table 3.

Table 3. HRES mixes found in the studied cases.

\begin{tabular}{ll}
\hline HRES mix & Cases \\
\hline $\mathrm{W}+\mathrm{S}+\mathrm{D}+\mathrm{B}$ & 25 \\
$\mathrm{~W}+\mathrm{S}+\mathrm{B}$ & 6 \\
$\mathrm{~W}+\mathrm{S}$ & 3 \\
$\mathrm{~W}+\mathrm{S}+\mathrm{D}$ & 3 \\
$\mathrm{~W}+\mathrm{S}+\mathrm{H}$ & 3 \\
$\mathrm{~W}+\mathrm{PSS}$ & 3
\end{tabular}

Note: B:Electrochemical battery; D:Diesel; H:Hydrogen+fuel cells; PSS:Pumped storage system; S:Solar; W:Wind.

\section{Discussion and conclusions}

Although important advances in electrification have been achieved globally, it must be noted that a large part of the world population — close to 0.9 billion in 2018 - still has no access to electricity. This situation occurs mainly in isolated areas, of which islands stand out, given their geographic characteristics. In this context, HRES optimisation appears to be a reliable alternative to the traditional use of fossil fuels, taking advantage of local renewable resources.

The current review of 73 island cases identifies three well-defined stages in a HRES optimisation: renewable energy assessment, energy consumption assessment, and sizing and energy optimisation. The first two stages require the collection of available information, ideally measured instrumentally.

Our analysis identifies the main limitations of studies dealing with HRES in islands, such as the frequent lack of hourly demand data and/or meteorological data - both of which are essential for renewable energy assessments. One of the most relevant issues is the lack of reliable data for an accurate assessment of the renewable resource(s) of each island, and subsequent adequate sizing of the HRES. Global and local models and in-situ measurements emerge as highly advisable. This is particularly evident in the case of wind data, where high spatial and temporal variability of this resource necessitates prioritization of in-situ measurements. On the other hand, global irradiation models provide a good representation of the solar resource data. Again, we emphasize that wind and solar resources are used in most of the analysed cases.

The convenience of using numerical weather prediction (NWP) models, such as Weather Research Forecasting (WRF) or Mesoscale Atmospheric Simulation System (MASS), is notable, particularly in cases when good quality meteorological data were not available. 
Nevertheless, in general, the use of this kind of model was not observed among the studied cases, suggesting that the HRES community is not yet regularly using such numerical tools.

We observed a significant lack of detailed energy demand information, for example hourly data with for periods of at least one year, which are essential for assessing seasonal variability. Several approaches were suggested for deriving these missing data, including the combination of top-down and bottom-up approaches. This method entails taking a top-down approach to consider the annual demand for a geographic unit of reference and scale it to the number and type of load units on the island, then employing a bottom-up approach to characterise demand profiles for each kind of unit until the annual demand assumption is obtained.

We found that the annual energy demand of islands follows their population number in a power law (linear when log-log scaled). As discussed earlier, annual energy values over the best fit curve are related to islands with tertiary economic activities; values under the best fit curve are related to islands with primary economic activities.

The use of energy storage units plays an important role in HRES optimisation, improving the performance of the entire system and resulting in an increase in RES penetration and a reduction of the effects of natural intermittence of renewable resources. The kind of energy storage system preferred is related to the size of the system or, more specifically, to the size of energy demand. Electrochemical batteries are associated with small and medium systems, while pumped storage seems to be suitable for large systems.

At least 20 optimisation models or methodologies were identified, of which HOMER software stands out, used in 30\% of the cases. These optimisation tools were applied either to specific stages of the optimisation or to the whole process, which demonstrates that there is no simple way to address the optimisation problem. In any case, and considering the factors emphasising sustainability, the authors of the current study recommend considering a multiobjective analysis approach which at least considers economic and environmental factors. It is important to point out that, while a wide range of cases were reviewed, new technologies, optimisation methodologies, and associated tools continue to emerge. Among them, Demand-Side Management stands out, which involves strategic actions that change consumer behaviours in order to reduce energy operating costs and/or energy consumption. Another important consideration is the significant progress that green hydrogen generation has achieved in recent years; by harnessing surplus energy, this is becoming a great opportunity to improve both the backup systems on HRES as well as the energy management strategies.

This review has demonstrated the feasibility of implementing HRES on islands, taking advantage of their specific geographic and climatic conditions. The proposed and/or implemented HRES reviewed offer an island the possibility of reducing its dependence on imported fossil fuels while also decreasing pollutant emission and favouring sustainable development. 


\section{Appendix A}

Studied islands with detailed characteristics (grouped by country).

Note: B:Battery, BD:Biodiesel, BG:Biogas, BM:Biomass, CSP:Concentrated Solar Power, D:Diesel, F:Flywheel, G:Geothermal, H:Hydrogen, Hy:Hydro, LA:Lead Acid, Li:Lithiumion, NaS:Sodium Sulfur, NG:Natural Gas, NiCd:Nickel Cadmium, PSS:Pumped Storage, RFB:Redox-flow Battery, S:Solar, Th:Thermal, Ti:Tidal, W:Wind, Wa:Waste, Wv:Wave. N/S:Not Specified.

\begin{tabular}{|c|c|c|c|c|c|c|}
\hline Island & Pop. & $\begin{array}{l}\text { Energy } \\
\text { Demand } \\
{[\mathrm{MWh} / \text { year }]}\end{array}$ & $\begin{array}{l}\text { Optmisation } \\
\text { Methodology }\end{array}$ & $\begin{array}{l}\text { Energy } \\
\text { Source }\end{array}$ & Storage & Reference \\
\hline Rapa Nui & 7,750 & 9,900 & ISOPROFIT & W,D & $\mathrm{N} / \mathrm{S}$ & Faúndez, 2017 \\
\hline Astypalaia & 1,334 & 6,250 & Toy model & $\begin{array}{l}\text { W,S,Hy,B, } \\
\text { Wv,G }\end{array}$ & PS & $\begin{array}{l}\text { Chalakatevaki et al., } \\
2017\end{array}$ \\
\hline Corvo & 425 & 884 & $\begin{array}{l}\text { RenewIsland }+\mathrm{H} 2 \\
\text { RES }\end{array}$ & W,Hy & PS & Duić et al., 2008 \\
\hline Malta & 409,259 & $2,885,976$ & H2RES & W,S & \multirow{4}{*}{$-\mathrm{H}$} & \multirow{4}{*}{ Krajačić et al., 2008} \\
\hline Mljet & 1,088 & $4,632.8$ & H2RES & W,S & & \\
\hline Porto Santo & 5,482 & 24,400 & $\mathrm{~N} / \mathrm{S}$ & W,S & & \\
\hline Terceira & 56,437 & 231,004 & H2RES & W,G,D & & \\
\hline Crete & 632,674 & $3,383,201$ & \multirow{4}{*}{ Model } & W & PS & \multirow{4}{*}{ Katsaprakakis, 2016} \\
\hline Rhodes & 115,490 & 789,168 & & W & PS & \\
\hline Samos & 32,977 & 168,862 & & W & PS & \\
\hline Kastelorizo & 492 & 3,510 & & W,S & $\mathrm{B}$ & \\
\hline Mykines & 20 & 0.157 & $\begin{array}{l}\text { Techno economic } \\
\text { model }\end{array}$ & W & $\mathrm{H}$ & $\begin{array}{l}\text { Enevoldsen \& } \\
\text { Sovacool, } 2016\end{array}$ \\
\hline Hvar & 11,459 & 45,933 & ENERGYPLAN & W,S & B & $\begin{array}{l}\text { Bačelić Medić et al., } \\
2013\end{array}$ \\
\hline Tac & 400 & 19.71 & HOMER & W,D & $\mathrm{B}$ & Stevens et al., 2001 \\
\hline Lesbos & 85,410 & 300,000 & $\mathrm{MOEA}+\mathrm{GA}$ & W,Hy,D & PS & $\begin{array}{l}\text { Papaefthymiou \& } \\
\text { Papathanassiou, } 2014\end{array}$ \\
\hline Isla Grande & 720 & $\mathrm{~N} / \mathrm{S}$ & $\mathrm{N} / \mathrm{S}$ & S,D & B & $\begin{array}{l}\text { Aguirre-Mendoza } \\
\text { et al., } 2019\end{array}$ \\
\hline Reunion & 837,900 & $2,545,000$ & $\begin{array}{l}\text { TIMES- } \\
\text { REUNION }\end{array}$ & $\begin{array}{l}\text { W,S,Hy,Wa, } \\
\text { G,Wv,BM }\end{array}$ & $\mathrm{N} / \mathrm{S}$ & Selosse et al., 2018 \\
\hline Miyako & 55,914 & $\mathrm{~N} / \mathrm{S}$ & \multirow{3}{*}{ GA } & \multirow{3}{*}{ W,S,D } & \multirow{3}{*}{ B } & \multirow{3}{*}{ Senjyu et al., 2007} \\
\hline Kume & 8,713 & $\mathrm{~N} / \mathrm{S}$ & & & & \\
\hline Tokashiki & 697 & $\mathrm{~N} / \mathrm{S}$ & & & & \\
\hline Eigg & 83 & 321.55 & HOMER & W,S,Hy,D & B & $\begin{array}{l}\text { Chmiel \& } \\
\text { Bhattacharyya, } 2015\end{array}$ \\
\hline Agios Efstratios & 270 & 1,223 & HOMER & W,S,D & RFB & Thomas et al., 2016 \\
\hline Malé & 133,412 & 108,000 & \multirow{5}{*}{$\begin{array}{l}\text { HOMER/DEFIN } \\
\text { ITE }\end{array}$} & \multirow{5}{*}{ W,S,D } & \multirow{5}{*}{ B } & \multirow{5}{*}{$\begin{array}{l}\text { van Alphen et al., } \\
2007\end{array}$} \\
\hline Fehendhoo & 245 & 365 & & & & \\
\hline Uligamu & 435 & 649.7 & & & & \\
\hline Nolhivaranfaru & 650 & 1,095 & & & & \\
\hline Hanimaadhoo & 1,009 & $2,792.25$ & & & & \\
\hline Kinmen & 123,723 & 254,452 & $\mathrm{~N} / \mathrm{S}$ & W,S & $\mathrm{N} / \mathrm{S}$ & $\begin{array}{l}\text { H.-Y. Liu \& Wu, } \\
2010\end{array}$ \\
\hline
\end{tabular}




\begin{tabular}{|c|c|c|c|c|c|c|}
\hline $\begin{array}{l}\text { Near Hong } \\
\text { Kong } \\
\text { (unidentified) }\end{array}$ & $\mathrm{N} / \mathrm{S}$ & $\mathrm{N} / \mathrm{S}$ & HOMER & $\mathrm{W}, \mathrm{S}$ & B & Ma et al., 2014 \\
\hline Thassos & 13,770 & 70,400 & $\begin{array}{l}\text { MCDA+REGIM } \\
\text { E }\end{array}$ & $\mathrm{W}, \mathrm{S}, \mathrm{BM}$ & $\mathrm{N} / \mathrm{S}$ & $\begin{array}{l}\text { Mourmouris \& } \\
\text { Potolias, } 2013\end{array}$ \\
\hline Awaji & 157,000 & $3,176,388$ & $\begin{array}{l}\text { Self Sufficiency } \\
\text { Ratio }\end{array}$ & $\mathrm{W}, \mathrm{S}$ & $\mathrm{N} / \mathrm{S}$ & $\begin{array}{l}\text { Sakaguchi \& Tabata, } \\
2015\end{array}$ \\
\hline Santay & 230 & 36.5 & HOMER & S,Hy,D & B & $\begin{array}{l}\text { Lata-García et al., } \\
2017\end{array}$ \\
\hline St. Martin & 8,000 & $\mathrm{~N} / \mathrm{S}$ & HOMER & W,S,BG,D & B & $\begin{array}{l}\text { Mazumder et al., } \\
2014\end{array}$ \\
\hline Ouessant & 846 & $\mathrm{~N} / \mathrm{S}$ & $\begin{array}{l}\text { Linear } \\
\text { Programming }\end{array}$ & W,S,Ti & B & $\begin{array}{l}\text { Mohammed et al., } \\
2016\end{array}$ \\
\hline Christmas & 2,072 & $\mathrm{~N} / \mathrm{S}$ & HOMER & W S.D & B & Orhan et al. 2014 \\
\hline Kangaroo & 4,417 & $\mathrm{~N} / \mathrm{S}$ & HOMIEK & $\mathrm{W}, \mathrm{S}, \mathrm{D}$ & B & Jornan et al., 2014 \\
\hline Flinders & 700 & $3,704.166$ & FL-GWO & $\mathrm{W}, \mathrm{S}, \mathrm{Ti}, \mathrm{D}$ & $\mathrm{Li}$ & El-Bidairi et al., 2018 \\
\hline Ometepe & 32,727 & 10,000 & $\mathrm{~N} / \mathrm{A}$ & $\mathrm{N} / \mathrm{S}$ & PS & Meza et al., 2019 \\
\hline Fournoi & 1,459 & 5,315 & $\begin{array}{l}\text { Method } \\
\text { Algorithm }\end{array}$ & W,Hy & PS & Bertsiou et al., 2018 \\
\hline Kavaratti & 11,210 & 12,730 & $\begin{array}{l}\text { HOMER+DigSIL } \\
\text { ENT }\end{array}$ & W,S,D & LA & Singh et al., 2017 \\
\hline Anafi & 423 & 1,277 & ESA & W,S,D & B & Tzanes et al., 2017 \\
\hline Tioman & 3.314 & 9,500 & HOMER & W,S,Hy,D & B & $\begin{array}{l}\text { Basir Khan et al., } \\
2015\end{array}$ \\
\hline Yong Shu & 500 & 45,400 & HOMER & W,S,D & $\mathrm{H}, \mathrm{B}, \mathrm{F}$ & Ye et al., 2017 \\
\hline Skiros & 2,994 & 16,207 & \begin{tabular}{|l|} 
EbsilonProfessiona \\
1+Exergetic \\
Analysis
\end{tabular} & W,CSP & $\mathrm{NaS}$ & $\begin{array}{l}\text { Petrakopoulou et al., } \\
2016\end{array}$ \\
\hline Deokjeok & 1,402 & 10,283 & \begin{tabular}{|l|} 
Linear \\
Programming $+\mathrm{H}$ \\
OMER
\end{tabular} & W,S,D & B & Shin et al., 2015 \\
\hline Man-Jae-Do & $\mathrm{N} / \mathrm{S}$ & 242.635 & \multirow{8}{*}{$\begin{array}{l}\text { Techno-economic } \\
\text { model }\end{array}$} & \multirow{8}{*}{ W,S,D } & \multirow{8}{*}{ B } & \multirow{8}{*}{ Ahadi et al., 2016} \\
\hline Sang-Tae-Do & $\mathrm{N} / \mathrm{S}$ & 257.016 & & & & \\
\hline $\begin{array}{l}\text { Yeong-San- } \\
\text { Do }\end{array}$ & $\mathrm{N} / \mathrm{S}$ & 168.118 & & & & \\
\hline Dok-Do & $\mathrm{N} / \mathrm{S}$ & 403.883 & & & & \\
\hline Woo-I-Do & $\mathrm{N} / \mathrm{S}$ & 653.09 & & & & \\
\hline Jang-Do & $\mathrm{N} / \mathrm{S}$ & 211.298 & & & & \\
\hline Jung-Ma-Do & $\mathrm{N} / \mathrm{S}$ & 85.42 & & & & \\
\hline Ha-Tae-Do & $\mathrm{N} / \mathrm{S}$ & 428.463 & & & & \\
\hline Utsira & 218 & 246 & $\begin{array}{l}\text { TRNSYS+HYD } \\
\text { ROGEMS }\end{array}$ & W & $\mathrm{H}, \mathrm{NiCd}$ & Ulleberg et al., 2010 \\
\hline Ventotene & 708 & $\mathrm{~N} / \mathrm{S}$ & $\begin{array}{l}\text { TRNSYS+HYD } \\
\text { ROGEMS }\end{array}$ & $\mathrm{W}, \mathrm{S}, \mathrm{Wv}$ & $\mathrm{H}$ & Corsini et al., 2009 \\
\hline Hainan & $8,600,000$ & $12,000,000$ & HOMER & W,S,Hy,NG & $\mathrm{N} / \mathrm{S}$ & Ye et al., 2012 \\
\hline Korčula & 15,522 & 46,060 & ENERGYPLAN & $\mathrm{W}, \mathrm{S}$ & B & Dorotić et al., 2019 \\
\hline $\begin{array}{l}\text { Karpathos- } \\
\text { Kasos }\end{array}$ & 7,310 & $42,199.199$ & Software & W,Hy & PS & $\begin{array}{l}\text { Katsaprakakis et al., } \\
2012\end{array}$ \\
\hline Cozumel & 79,535 & 261,000 & $\begin{array}{l}\text { HOMER+RETS } \\
\text { creen }\end{array}$ & W,S,D & $\mathrm{N} / \mathrm{S}$ & $\begin{array}{l}\text { Mendoza-Vizcaino } \\
\text { et al., } 2016\end{array}$ \\
\hline São Vicente & 74,031 & 57,000 & H2RES & W,Hy,Th & PS & Segurado et al., 2011 \\
\hline
\end{tabular}


James Morales Lassalle, Dante Figueroa Martínez, \& Luis Vergara Fernández

\begin{tabular}{|c|c|c|c|c|c|c|}
\hline Canarias & $2,120,000$ & $8,223,000$ & \begin{tabular}{|l} 
Mesap- \\
PlaNet+REMix
\end{tabular} & $\begin{array}{l}\text { W,S,CSP,Hy } \\
\text {,G,Wv,BM }\end{array}$ & $\begin{array}{l}\text { PS,FFB, } \\
\mathrm{H} \\
\end{array}$ & Gils \& Simon, 2017 \\
\hline Pulau Ubin & 200 & $\mathrm{~N} / \mathrm{S}$ & TRNSYS & S,CSP,BM & $\mathrm{H}$ & Chua et al., 2014 \\
\hline Mykonos & 10,134 & 43,612 & $\mathrm{~N} / \mathrm{S}$ & W,S,D & $\mathrm{N} / \mathrm{S}$ & Economou, 2010 \\
\hline Salina & 2,504 & $10,859.5$ & TRNSYS & W,S & $N / S$ & Andaloro et al., 2012 \\
\hline $\begin{array}{l}\text { Wang- } \\
\text { An/Jian-Jun- } \\
\mathrm{Ou}\end{array}$ & 3,289 & 6,400 & EnergyPLAN & $\mathrm{W}, \mathrm{S}, \mathrm{Wv}, \mathrm{BM}$ & $\mathrm{N} / \mathrm{S}$ & Yue et al., 2016 \\
\hline Lençóis & 390 & 72.889 & $\mathrm{~N} / \mathrm{S}$ & W,S,D & $\mathrm{B}$ & Ribeiro et al., 2012 \\
\hline Vis & 3,617 & 13,158 & HOMER & S & $\mathrm{B}, \mathrm{H}$ & Pfeifer et al., 2017 \\
\hline El Hierro & 11,178 & 45,000 & MILP & $\mathrm{W}, \mathrm{Hy}, \mathrm{D}$ & PS & Pezic \& Cedrés, 2013 \\
\hline Oahu & 976,372 & $7,561,000$ & $\mathrm{~N} / \mathrm{S}$ & W,S,D & $\mathrm{N} / \mathrm{S}$ & Schuerger et al., 2013 \\
\hline Prince Edward & 142,907 & $2,000,000$ & GA & W,S,BM & $\mathrm{Li}$ & $\begin{array}{l}\text { Hall \& Swingler, } \\
2018\end{array}$ \\
\hline Perhentian & 2,000 & $\mathrm{~N} / \mathrm{S}$ & $\mathrm{N} / \mathrm{S}$ & W,S,D & B & Darus et al., 2009 \\
\hline Gökceada & 8,766 & $\mathrm{~N} / \mathrm{S}$ & HOMER & W,S,D & B & $\begin{array}{l}\text { Demiroren \& Yilmaz, } \\
2010\end{array}$ \\
\hline Gadeokdo & 3,800 & 12,390 & HOMER & W,S & B & Park \& Kwon, 2016 \\
\hline
\end{tabular}

\section{References}

Aguirre-Mendoza, A. M., Díaz-Mendoza, C., \& Pasqualino, J. (2019). Renewable energy potential analysis in non-interconnected islands. Case study: Isla Grande, Corales del Rosario Archipelago, Colombia. Ecological Engineering, 130, 252-262. https://doi.org/10.1016/j.ecoleng.2017.08.020

Ahadi, A., Kang, S.-K., \& Lee, J.-H. (2016). A novel approach for optimal combinations of wind, PV, and energy storage system in diesel-free isolated communities. Applied Energy, 170, 101-115. https://doi.org/10.1016/j.apenergy.2016.02.110

Andaloro, A. P. F., Salomone, R., Andaloro, L., Briguglio, N., \& Sparacia, S. (2012). Alternative energy scenarios for small islands: A case study from Salina Island (Aeolian Islands, Southern Italy). Renewable Energy, 47, 135-146. https://doi.org/10.1016/j.renene.2012.04.021

Bačelić Medić, Z., Ćosić, B., \& Duić, N. (2013). Sustainability of remote communities: 100\% renewable island of Hvar. Journal of Renewable and Sustainable Energy, 5(4), 041806. https://doi.org/10.1063/1.4813000

Bahramara, S., Moghaddam, M. P., \& Haghifam, M. R. (2016). Optimal planning of hybrid renewable energy systems using HOMER: A review. Renewable and Sustainable Energy Reviews, 62, 609-620. https://doi.org/10.1016/j.rser.2016.05.039

Basir Khan, M. R., Jidin, R., Pasupuleti, J., \& Shaaya, S. A. (2015). Optimal combination of solar, wind, micro-hydro and diesel systems based on actual seasonal load profiles for a resort island in the South China Sea. Energy, 82, 80-97. https://doi.org/10.1016/j.energy.2014.12.072

Bertsiou, M., Feloni, E., Karpouzos, D., \& Baltas, E. (2018). Water management and electricity output of a Hybrid Renewable Energy System (HRES) in Fournoi Island in $\begin{array}{lllll}\text { Aegean Sea. Renewable } \quad \text { Energy, } & \text { 118, 790. }\end{array}$ https://doi.org/10.1016/j.renene.2017.11.078 
Blechinger, P., Cader, C., Bertheau, P., Huyskens, H., Seguin, R., \& Breyer, C. (2016). Global analysis of the techno-economic potential of renewable energy hybrid systems on small islands. Energy Policy, 98, 674-687. https://doi.org/10.1016/j.enpol.2016.03.043

Brito, M. C., Lobato, K., Nunes, P., \& Serra, F. (2014). Sustainable energy systems in an imaginary island. Renewable and Sustainable Energy Reviews, 37, 229-242. https://doi.org/10.1016/j.rser.2014.05.008

Chalakatevaki, M., Stamou, P., Karali, S., Daniil, V., Dimitriadis, P., Tzouka, K., Iliopoulou, T., Koutsoyiannis, D., Papanicolaou, P., \& Mamassis, N. (2017). Creating the electric energy mix in a non-connected island. Energy Procedia, 125, 425-434. https://doi.org/10.1016/j.egypro.2017.08.089

Chmiel, Z., \& Bhattacharyya, S. C. (2015). Analysis of off-grid electricity system at Isle of Eigg (Scotland): Lessons for developing countries. Renewable Energy, 81, 578-588. https://doi.org/10.1016/j.renene.2015.03.061

Chua, K. J., Yang, W. M., Er, S. S., \& Ho, C. A. (2014). Sustainable energy systems for a remote island community. Applied Energy, 113, 1752-1763. https://doi.org/10.1016/j.apenergy.2013.09.030

Corsini, A., Rispoli, F., Gamberale, M., \& Tortora, E. (2009). Assessment of $\mathrm{H}_{2}-$ and $\mathrm{H}_{2} \mathrm{O}-$ based renewable energy-buffering systems in minor islands. Renewable Energy, 34(1), 279-288. https://doi.org/10.1016/j.renene.2008.03.005

Darus, Z., Hashim, N. A., Manan, S. N. A., Rahman, M. A. A., Maulud, K. N. A., \& Karim, O. A. (2009). The development of hybrid integrated renewable energy system (wind and solar) for sustainable living at Perhentian Island, Malaysia. European Journal of Social Sciences, 9(4), 557-563.

Demiroren, A., \& Yilmaz, U. (2010). Analysis of change in electric energy cost with using renewable energy sources in Gökceada, Turkey: An island example. Renewable and Sustainable Energy Reviews, 14(1), 323-333. https://doi.org/10.1016/j.rser.2009.06.030

Dorotić, H., Doračić, B., Dobravec, V., Pukšec, T., Krajačić, G., \& Duić, N. (2019). Integration of transport and energy sectors in island communities with $100 \%$ intermittent renewable energy sources. Renewable and Sustainable Energy Reviews, 99, 109-124. https://doi.org/10.1016/j.rser.2018.09.033

Drouineau, M., Assoumou, E., Mazauric, V., \& Maïzi, N. (2015). Increasing shares of intermittent sources in Reunion Island: Impacts on the future reliability of power supply. Renewable and Sustainable Energy Reviews, 46, 120-128. https://doi.org/10.1016/j.rser.2015.02.024

Duić, N., Krajačić, G., \& da Graça Carvalho, M. (2008). RenewIslands methodology for sustainable energy and resource planning for islands. Renewable and Sustainable Energy Reviews, 12(4), 1032-1062. https://doi.org/10.1016/j.rser.2006.10.015

Economou, A. (2010). Renewable energy resources and sustainable development in Mykonos (Greece). Renewable and Sustainable Energy Reviews, 14(5), 1496-1501. https://doi.org/10.1016/j.rser.2009.11.008 
El-Bidairi, K. S., Duc Nguyen, H., Jayasinghe, S. D. G., Mahmoud, T. S., \& Penesis, I. (2018). A hybrid energy management and battery size optimization for standalone microgrids: A case study for Flinders Island, Australia. Energy Conversion and Management, 175, 192-212. https://doi.org/10.1016/j.enconman.2018.08.076

Enevoldsen, P., \& Sovacool, B. K. (2016). Integrating power systems for remote island energy supply: Lessons from Mykines, Faroe Islands. Renewable Energy, 85, 642-648. https://doi.org/10.1016/j.renene.2015.06.065

Faúndez, P. (2017). Renewable energy in the equilibrium mix of electricity supply sources. Energy Economics, 67, 28-34. https://doi.org/10.1016/j.eneco.2017.07.015

Gils, H. C., \& Simon, S. (2017). Carbon neutral archipelago - 100\% renewable energy supply for the Canary Islands. Applied Energy, 188, 342-355.

https://doi.org/10.1016/j.apenergy.2016.12.023

Graham, V. A., \& Hollands, K. G. T. (1990). A method to generate synthetic hourly solar radiation globally. Solar Energy, 44(6), 333-341. https://doi.org/10.1016/0038092X(90)90137-2

Hall, M., \& Swingler, A. (2018). Initial perspective on a 100\% renewable electricity supply for Prince Edward Island. International Journal of Environmental Studies, 75(1), 135-153. https://doi.org/10.1080/00207233.2017.1395246

International Energy Agency. (2019). SDG7: Data and projections. Reports. https://www.iea.org/reports/sdg7-data-and-projections

International Energy Agency. (2018). $\mathrm{CO}_{2}$ Emissions from Fuel Combustion - 2018 Highlights. International Energy Agency \& OECD.

Ioannidis, A., \& Chalvatzis, K. J. (2017). Energy supply sustainability for island nations: A study on 8 global islands. Energy Procedia, 142, 3028-3034. https://doi.org/10.1016/j.egypro.2017.12.440

Kaldellis, J. K., Gkikaki, A., Kaldelli, E., \& Kapsali, M. (2012). Investigating the energy autonomy of very small non-interconnected islands: A case study: Agathonisi, Greece. Energy for Sustainable Development, 16(4), 476-485. https://doi.org/10.1016/j.esd.2012.08.002

Katsaprakakis, D. A. (2016). Hybrid power plants in non-interconnected insular systems. Applied Energy, 164, 268-283. https://doi.org/10.1016/j.apenergy.2015.11.085

Katsaprakakis, D. A., Christakis, D. G., Pavlopoylos, K., Stamataki, S., Dimitrelou, I., Stefanakis, I., \& Spanos, P. (2012). Introduction of a wind powered pumped storage system in the isolated insular power system of Karpathos-Kasos. Applied Energy, 97, 3848. https://doi.org/10.1016/j.apenergy.2011.11.069

Kennedy, N., Miao, C., Wu, Q., Wang, Y., Ji, J., \& Roskilly, T. (2017). Optimal hybrid power system using renewables and hydrogen for an isolated island in the UK. Energy Procedia, 105, 1388-1393. https://doi.org/10.1016/j.egypro.2017.03.517

Kougias, I., Szabó, S., Nikitas, A., \& Theodossiou, N. (2019). Sustainable energy modelling of non-interconnected Mediterranean islands. Renewable Energy, 133, 930-940. https://doi.org/10.1016/j.renene.2018.10.090

Krajačić, G., Martins, R., Busuttil, A., Duić, N., \& da Graça Carvalho, M. (2008). Hydrogen as an energy vector in the islands' energy supply. International Journal of Hydrogen Energy, 33(4), 1091-1103. https://doi.org/10.1016/j.ijhydene.2007.12.025 
Kuang, Y., Zhang, Y., Zhou, B., Li, C., Cao, Y., Li, L., \& Zeng, L. (2016). A review of renewable energy utilization in islands. Renewable and Sustainable Energy Reviews, 59, 504-513. https://doi.org/10.1016/j.rser.2016.01.014

Lata-García, J., Reyes-López, C., Jurado, F., Fernández-Ramírez, Luis. M., \& Sánchez, H. (2017). Sizing optimization of a small hydro/photovoltaic hybrid system for electricity generation in Santay Island, Ecuador by two methods. 2017 CHILEAN Conference on Electrical, Electronics Engineering, Information and Communication Technologies (CHILECON). https://doi.org/10.1109/CHILECON.2017.8229539

Lin, J.-H., Wu, Y.-K., \& Lin, H.-J. (2016). Successful experience of renewable energy development in several offshore islands. Energy Procedia, 100, 8-13. https://doi.org/10.1016/j.egypro.2016.10.137

Liu, H., \& Qu, S. (2014). The optimal capacity and economic analysis of micro-grid on island. OCEANS 2014 - TAIPEI. https://doi.org/10.1109/OCEANS_TAIPEI.2014.6964426

Liu, H.-Y., \& Wu, S.-D. (2010). An assessment on the planning and construction of an island renewable energy system - A case study of Kinmen Island. Renewable Energy, 35(12), 2723-2731. https://doi.org/10.1016/j.renene.2010.04.021

Liu, Y., Yu, S., Zhu, Y., Wang, D., \& Liu, J. (2018). Modeling, planning, application and management of energy systems for isolated areas: A review. Renewable and Sustainable Energy Reviews, 82, 460-470. https://doi.org/10.1016/j.rser.2017.09.063

Ma, T., Yang, H., \& Lu, L. (2014). A feasibility study of a stand-alone hybrid solar-windbattery system for a remote island. Applied Energy, 121, 149-158. https://doi.org/10.1016/j.apenergy.2014.01.090

Mahesh, A., \& Sandhu, K. S. (2015). Hybrid wind/photovoltaic energy system developments: Critical review and findings. Renewable and Sustainable Energy Reviews, 52, 1135-1147. https://doi.org/10.1016/j.rser.2015.08.008

Manwell, J. F. (2004). Hybrid energy systems. In C. J. Cleveland (Ed.), Encyclopedia of energy (pp. 215-229). Elsevier. https://doi.org/10.1016/B0-12-176480-X/00360-0

Mazumder, P., Jamil, M. H., Das, C. K., \& Matin, M. A. (2014). Hybrid energy optimization: An ultimate solution to the power crisis of St. Martin Island, Bangladesh. 2014 9th International Forum on Strategic Technology (IFOST), 363-368. https://doi.org/10.1109/IFOST.2014.6991141

Mendoza-Vizcaino, J., Sumper, A., Sudria-Andreu, A., \& Ramirez, J. M. (2016). Renewable technologies for generation systems in islands and their application to Cozumel Island, Mexico. Renewable and Sustainable Energy Reviews, 64, 348-361. https://doi.org/10.1016/j.rser.2016.06.014

Meza, C. G., Zuluaga Rodríguez, C., D’Aquino, C. A., Amado, N. B., Rodrigues, A., \& Sauer, I. L. (2019). Toward a 100\% renewable island: A case study of Ometepe's energy mix. Renewable Energy, 132, 628-648. https://doi.org/10.1016/j.renene.2018.07.124

Mohammed, O. H., Amirat, Y., Benbouzid, M., Haddad, S., \& Feld, G. (2016). Optimal sizing and energy management of hybrid wind/tidal/PV power generation system for remote areas: Application to the Ouessant French Island. IECON 2016 - 42nd Annual Conference of the IEEE Industrial Electronics Society, 4205-4210. https://doi.org/10.1109/IECON.2016.7793976 
Mourmouris, J. C., \& Potolias, C. (2013). A multi-criteria methodology for energy planning and developing renewable energy sources at a regional level: A case study Thassos, Greece. Energy Policy, 52, 522-530. https://doi.org/10.1016/j.enpol.2012.09.074

Orhan, T., Shafiullah, G. M., Stojcevski, A., \& Oo, A. (2014). A feasibility study on microgrid for various Islands in Australia. 2014 Australasian Universities Power Engineering Conference (AUPEC). https://doi.org/10.1109/AUPEC.2014.6966604

Papaefthymiou, S. V., \& Papathanassiou, S. A. (2014). Optimum sizing of wind-pumpedstorage hybrid power stations in island systems. Renewable Energy, 64, 187-196. https://doi.org/10.1016/j.renene.2013.10.047

Papaefthymiou, S. V., Lakiotis, V. G., Margaris, I. D., \& Papathanassiou, S. A. (2015). Dynamic analysis of island systems with wind-pumped-storage hybrid power stations. Renewable Energy, 74, 544-554. https://doi.org/10.1016/j.renene.2014.08.062

Park, E., \& Kwon, S. J. (2016). Towards a sustainable island: Independent optimal renewable power generation systems at Gadeokdo Island in South Korea. Sustainable Cities and Society, 23, 114-118. https://doi.org/10.1016/j.scs.2016.02.017

Petrakopoulou, F., Robinson, A., \& Loizidou, M. (2016). Simulation and evaluation of a hybrid concentrating-solar and wind power plant for energy autonomy on islands. Renewable Energy, 96(A), 863-871. https://doi.org/10.1016/j.renene.2016.05.030

Pezic, M., \& Cedrés, V. M. (2013). Unit commitment in fully renewable, hydro-wind energy systems. 2013 10th International Conference on the European Energy Market (EEM). https://doi.org/10.1109/EEM.2013.6607331

Pfeifer, A., Bošković, F., Dobravec, V., Matak, N., Krajačić, G., Duić, N., \& Pukšec, T. (2017). Building smart energy systems on Croatian islands by increasing integration of renewable energy sources and electric vehicles. 2017 IEEE International Conference on Environment and Electrical Engineering and 2017 IEEE Industrial and Commercial Power Systems Europe (EEEIC I IECPS Europe). https://doi.org/10.1109/EEEIC.2017.7977401

Ribeiro, L. A. de S., Saavedra, O. R., Lima, S. L., de Matos, J. G., \& Bonan, G. (2012). Making isolated renewable energy systems more reliable. Renewable Energy, 45, 221231. https://doi.org/10.1016/j.renene.2012.02.014

Sakaguchi, T., \& Tabata, T. (2015). 100\% electric power potential of PV, wind power, and biomass energy in Awaji island Japan. Renewable and Sustainable Energy Reviews, 51, 1156-1165. https://doi.org/10.1016/j.rser.2015.06.056

Schuerger, M., Johal, H., Roose, L., Matsuura, M., \& Piwko, R. (2013). Catching some rays: Variable generation integration on the island of Oahu. IEEE Power and Energy Magazine, 11(6), 33-44. https://doi.org/10.1109/MPE.2013.2277998

Segurado, R., Krajačić, G., Duić, N., \& Alves, L. (2011). Increasing the penetration of renewable energy resources in S. Vicente, Cape Verde. Applied Energy, 88(2), 466-472. https://doi.org/10.1016/j.apenergy.2010.07.005

Selosse, S., Garabedian, S., Ricci, O., \& Maïzi, N. (2018). The renewable energy revolution of Reunion Island. Renewable and Sustainable Energy Reviews, 89, 99-105. https://doi.org/10.1016/j.rser.2018.03.013 
Senjyu, T., Hayashi, D., Yona, A., Urasaki, N., \& Funabashi, T. (2007). Optimal configuration of power generating systems in isolated island with renewable energy. Renewable Energy, 32(11), 1917-1933. https://doi.org/10.1016/j.renene.2006.09.003

Shin, Y., Koo, W. Y., Kim, T. H., Jung, S., \& Kim, H. (2015). Capacity design and operation planning of a hybrid PV-wind-battery-diesel power generation system in the case of Deokjeok Island. Applied Thermal Engineering, 89, 514-525. https://doi.org/10.1016/j.applthermaleng.2015.06.043

Siddaiah, R., \& Saini, R. P. (2016). A review on planning, configurations, modeling and optimization techniques of hybrid renewable energy systems for off grid applications. Renewable and Sustainable Energy Reviews, 58, 376-396. https://doi.org/10.1016/j.rser.2015.12.281

Singh, G., Baredar, P., Singh, A., \& Kurup, D. (2017). Optimal sizing and location of PV, wind and battery storage for electrification to an island: A case study of Kavaratti, Lakshadweep. Journal of Energy Storage, 12, 78-86. https://doi.org/10.1016/j.est.2017.04.003

Sinha, S., \& Chandel, S. S. (2014). Review of software tools for hybrid renewable energy systems. Renewable and Sustainable Energy Reviews, 32, 192-205. https://doi.org/10.1016/j.rser.2014.01.035

Stevens, N. E., Castillo, J., Baring-Gould, I., \& Lagos, W. (2001). Isla Tac power system first year status report: October 2000 through October 2001 [Doc. TR-Tac-11-2001]. Wireless Energy. content/uploads/2012/01/Final Tac Report 1 Yr.pdf

Thomas, D., Deblecker, O., \& Ioakimidis, C. S. (2016). Optimal design and technoeconomic analysis of an autonomous small isolated microgrid aiming at high RES penetration. Energy, 116 (Part 1 364-379. https://doi.org/10.1016/j.energy.2016.09.119

Tzanes, G. T., Zafirakis, D., Papapostolou, C., Kavadias, K., \& Kaldellis, J. K. (2017). PHAROS: An integrated planning tool for meeting the energy and water needs of remote islands using RES-based hybrid solutions. Energy Procedia, 142, 2586-2591. https://doi.org/10.1016/j.egypro.2017.12.196

Ulleberg, Ø., Nakken, T., \& Eté, A. (2010). The wind/hydrogen demonstration system at Utsira in Norway: Evaluation of system performance using operational data and updated hydrogen energy system modeling tools. International Journal of Hydrogen Energy, 35(5), 1841-1852. https://doi.org/10.1016/j.ijhydene.2009.10.077

United Nations. (2015). Transforming our world: The 2030 agenda for sustainable development (A/RES/70/1).

https://sustainabledevelopment.un.org/post2015/transformingourworld

van Alphen, K., van Sark, W. G. J. H. M., \& Hekkert, M. P. (2007). Renewable energy technologies in the Maldives- Determining the potential. Renewable and Sustainable Energy Reviews, 11(8), 1650-1674. https://doi.org/10.1016/j.rser.2006.02.001

Ye, B., Tang, J., \& Lu, Q. (2012). Feasibility analysis of renewable energy powered tourism island-Hainan, China. Journal of Renewable and Sustainable Energy, 4(6), 063127. https://doi.org/10.1063/1.4767836 
James Morales Lassalle, Dante Figueroa Martínez, \& Luis Vergara Fernández

Ye, B., Zhang, K., Jiang, J., Miao, L., \& Li, J. (2017). Towards a 90\% renewable energy future: A case study of an island in the South China Sea. Energy Conversion and Management, 142, 28-41. https://doi.org/10.1016/j.enconman.2017.03.038

Yue, C.-D., Chen, C.-S., \& Lee, Y.-C. (2016). Integration of optimal combinations of renewable energy sources into the energy supply of Wang-An Island. Renewable Energy, 86, 930-942. https://doi.org/10.1016/j.renene.2015.08.073 